\title{
Positive selection for gene-modifiers is the way for fixation of the hereditary changes in populations
}

\author{
Yu. V. Vagin \\ The Institute of Molecular Biology and Genetics \\ 150 Zabolotny Str., Kyiv 03143, Ukraine
}

\begin{abstract}
The presence of the way for fixation of the hereditary changes in populations has been substantiated. It can be realized due to gene-modifiers selection. Accordingly, the role of the above genes on the one hand may involve the de novo arising mutations rendering harmless, while on the other hand-their assimilation.
\end{abstract}

Keywords: positive selection, gene-modifiers, mink, blastocyst, homeostasis.

Earlier it has been established [1] that the progeny of silver-blue females (heterogeneous by aleutian ( $p p A a$ ) and sapphire males of minks experienced the significant deficiency of sapphire kits in the course of five seasons of reproduction. The study on the reasons resulting in such disorder revealed the influence of selective elimination of ppaa embryos [2]. Besides, the progeny, successfully implanted and completed its prenatal development in post-natal period, was shown to possess the increased levels of all components fitness [1].

Regular is the question - why one part of ppaa embryos is subjected to the selective elimination during the implantation and the other part is successfully implemented, having competed $p p A a$ embryos for the implantation places?

The increase in fitness of successfully implanted and new-born sapphire progeny, as well as some other necessary evidences $[1,2]$, point at the fact that this progeny has gone through "screening" of positive selection in $p p A a$ mothers' wombs. Evidently, such se-

(c) YU. V. VAGIN, 2007 lective process, as well as any other process, could take place at the condition of the existence of different genetic differences [3] between implanted and eliminated ppaa embryos. Having understood the essence of these differences, we would be able to answer the aforementioned question.

A significant number of facts, demonstrating the inhibiting effect of recessive homozygote Aleutian on reproductive function of minks are known. In particular, sapphire females were noted for decreased fertility compared to silver-blue $p p A A$ and $p p A a$. At the same time they were detected to have a high percentage of bred females having no litter, shifting of the dates of first breeding along with later implantation terms, extended rutting and delivering terms, as well as prolonged gestation period, compared to both silver-blue and standard females [4-6].

In addition, sapphire females, versus silver-blue ones, were specific for high level of early post-natal withdrawal of young growths [4]. It has been established also that the growth rate of sapphire minks is lower than the one of silver-blue minks [7]. 
Therefore, $p p A a$ and $p p A A$ minks were revealed to have higher values of all fitness components, i.e. fertility, viability, growth rate, than the ppaa minks.

Thus, the listed-above facts make a distinct point that the absence of recessive homozygote gene Aleutian - $a a-$ in minks results in decrease of their fitness indices. As it was stated by Fisher [8], the selection of modifier genes assists gradual elimination of such defects. According to the hands-on opinion of nowadays [8-10], low penetrance and expressivity of recessive mutations in specimen, isolated from natural populations, testifies in favor of selection on the bases of mentioned genes.

Sapphire minks, subdued to the positive selection, the descendents of $p p A a$ females and ppaa males, were observed to have the increase in basic components of fitness [1]. These very consequences were forecasted at positive selection effect, directed towards the selection of modifier genes [8-10].

Stating on the presented above, the plausible answer to the question on the essence of genetic differences between selected and eliminated sapphire progeny may be the following: the part of progeny, which went through the "screening" of positive selection, and the other part, which was eliminated, differ in one single thing - the presence or absence of modifier genes in the genotypes of their own.

Accordingly, sapphire blastocysts with safe "ontogenetic destiny" include modifier genes, which significantly level the negative effect of recessive homozygote Aleutian on the process of implantation. In this situation, the biological effect of the mentioned genes is connected to the leveling of successful possibilities for implantation of ppaa and $p p A a$ blastocysts.

Besides, the effect of modifiers is most probably reflected on the development of sapphire progeny in the post-natal period. It is indicated by the assessment of basic components of fitness (fertility, viability, and growth rate) of ppaa minks, born from $p p A a$ mothers; the indices of the latter excel those of ppaa minks, born from ppaa mothers [1].

Therefore, the combined implantation of $p p A a$ and ppaa blastocysts, the positive selection is apparently directed to ppaa blastocysts, genotypes of which contain modifier genes.
Positive selection, playing the "creative role" in morphological evolution of organisms, is presented in stabilizing and directing types [11]. Generally, positive selection provides maintenance and reconstruction of morphogenetic development program. However, depending on the ecological situation [12], one of its two types takes the leading role in form-building process. Thus, in the conditions of continuous single-vector change in specimen environment, the effect of directing positive selection prevails [11]. This effect is connected with morphogenetic development program for specimen, aimed at the formation of new adaptive biological norm $[11,12]$. In the course of such selection, the qualitative change in the mentioned program, it basically lies in the reorganization of gene pool according to the new ecological requirements, takes place $[9,12]$.

In the opposite ecological situation, when the organism is experiencing pressure from the fluctuating environment conditions, the effect of positive stabilizing selection steps forward [11]. This effect is directed towards the maintenance and strengthening of current adaptive norm, formed in the process of species evolution $[9,11]$. Meanwhile, the program of organism's personal development is mostly preserved, and the selection fixes the genes, which adjust perturbing influence of the environment on the morphogenetic process [12]. In this exact way it is possible to decrease significantly the environmental effect on ontogenesis.

As it is presented by Neo-Darwinists and the supporters of evolutionary synthesis, natural selection increases the tolerance of the realization process of organisms' morphological programs in the course of their historical development [13-15]. As a result, personal development of the organism becomes more secured from perturbing effect of various environmental factors. One of the most important of these factors is the pressure of mutational press $[9,10]$. Thus, special attention is paid to the answer to the question - how to achieve the necessary protection of morphogenetic program?

According to the author's opinion, modifier genes are the most probable protectors of the program. Along with arguments in short communications [8-10], the results of our investigation and the conclusions made whereupon are presented as evidences $[1,2]$. 
According to modern views on evolution, current mechanism of protection of genetic program by modifier genes is formed and secured by means of positive selection [8-10]. The mechanism's efficiency is forecasted to be higher in case of selections at the early stages of ontogenesis $[11,12]$, which is conditioned by clear-cut dependence, i.e. the earlier genetic changes occur, the stronger (evenly increasing) are conditioned distant morphological changes in the developing organism [13].

However, mutational press includes a good seed as well, as mutations are considered to be one of the sources of genetic pool enrichment. A high diversity degree is determined as the crucial factor for the application of genetic pool by natural selection for solving the problems due to the adaptation of organisms towards variable ecological requirements $[9,10]$. The impoverishment of genetic variety of population is considered to be the weakening determinant of its evolutionary perspectives $[3,9-11]$.

In such conditions, the effect of positive selection has got to be directed towards the acquisition of a certain balance, during which, on the one hand, the collection of genes, providing constant development of normal phenotype, has to be preserved, and, on the other hand, securing of new genes, enriching the "mobilization back-up" of variability [16], necessary for preservation of population plasticity.

The mentioned balance may be achieved, first of all, by means of fixation and accumulation of modifier genes by positive selection. As the accumulation proceeds, modifier genes gradually smoothen up the negative effects of de novo mutations, which helps preserving the normal process of personal development. Thereby, the positive selection consolidates a certain set of genes, comprising the hereditary program in the series of generations, as well as increases the interference immunity of current program; the system of genetic homeostasis is being formed [17], which provides channeling for personal development of the organism [15].

Therefore, the "idea" of protection of morphogenetic program, providing the formation of generic phenotype of species is realized.

The selective work, connected with assimilation of mutant genes, "rendered harmless" by modifier genes, is taking place at the same time. As a result, it is possible to maintain a certain level of genetic pool variability, which allows the population to preserve its necessary adaptive plasticity, and, consequently, evolutionary perspectives [9-11].

In accordance to Charles R. Darwin's idea, which acquired new life in the works of Neo-Darwinists, natural selection accumulates positive mutations in the populations, which increase the fitness of specimens, and, therefore, providing the latter with higher evolutionary success $[9,10]$. However, mutations, providing fitness of individuals, are very rarely to be found $[3,8-10]$. At the same time, the majority of occurring de novo mutations sharply decreases the fitness of their carriers, and the latter [carriers] are, as a rule, eliminated [9-11].

One more way of accumulation of mutations has been theoretically substantiated. This way states that the dominant role in the given events is giver to stochastic processes, which determine the fixation of neutral or low-negative mutations inside the population [18].

The existence of the third way of fixation, maintaining genetic variability and adaptive plasticity of the population, is also possible. This way, as well as the other two mentioned, provides the formation of "mobilization back-up" [16] of genetic variability of population. Although it is not connected with the natural selection effect, directed towards the fixation of positive mutations, providing their carriers with higher degree of fitness. Head-on movement implies the neutralization of negative effect of moderately malicious mutaions (those that decrease the level of fitness of specimens, but not semi-lethal and lethal ones) and their subsequent selective fixation. This result is achieved by means of positive selection of modifier genes.

Initial fixation of modifier genes as a part genetic pool of the population allows further "rendering harmless" of moderately malicious mutations. Therefore, the stability of the process of morphological program realization and, consequently, the homeostasis of specimen development, are increased.

Selective fixation of "neutralized" mutations, in its turn, enriches the genetic population and consequently increases their adaptive selectivity. 
The results of palaeontological research reveal that the historical development of organisms is characterized by a rather long (geological-scale-wise) periods, in the course of which, the rate of evolutionary process was approximately even and insufficient $[13,14]$. However, such evenness was interrupted by the periods of rapid acceleration of form-forming process - the explosion of species-formation [10, 13, 14].

According to Rudolf A. Raff and Thomas C. Kaufman [13], the acceleration of the evolutionary process is conditioned by the effect of positive selection of the positive type, which provides the selection of genes, responsible for regulation of morphogenesis. Thus, the re-arrangement of morphogenetic programs takes place if a short time, the target of which is the formation of updated phenotypes, corresponding, to a great degree, the requirements of changed ecological environment.

At the same time, low-rates of evolutionary process are specific for protracted stability of their forms. Morphological stability is defined by relatively constant conditions of ecological existence of organisms and is provided by stabilizing positive selection [11]. However, the preservation of historically-formed phenotype is not considered to be the result of conservation of morphogenetic program of organism's [11, 12]. Its (program's) long-term stabilization is achieved, to the great degree, by selection of modifier genes. At the same time the role of the indicated genes, on the one hand, is connected with "rendering harmless" of de novo mutations appeared, and, on the other hand, with their assimilation. In the same way the process of normal personal development and enrichment of population genetic pool is achieved.

According to the palaeontological data, the historical development of organisms takes place at the conditions of low evolutionary rates $[13,14]$. As it is presented by authors in [13], "unhasting" process of historical changeability of the organisms acquires satisfactory explanation within STE on the process of microevolution, which proceeds the way of selection of structural genes.

Therefore, there is a foundation to suppose that the biggest part of natural history of organisms develops under the influence of stabilizing positive selection, the results of which are the preservation of morphological norm and the formation of "mobilising back-up" of genetic variability of populations, achieved due to the selection of modifier genes.

\section{Ю. В. Вагин}

Положительный отбор генов-модификаторов - путь фиксации наследственных изменений в популяциях

Резюме

Обосновано наличие пути закрепления наследственных изменений в популяциях, достигающееся за счет селекции генов-модификаторов. При этом роль указанных генов, с одной стороны, связана с «обезвреживанием» возникающих de поvо мутаций, а с другой, - с их ассимиляцией.

Ключевые слова: положительный отбор, гень-модификаторы, норка, бластоциста, гомеостаз.

\section{REFERENCES}

1. Вагин Ю. В. Дарвиновский отбор на пренатальной стадии онтогенеза у норок Mustela vison: факты // Доп. НАН України.-2004.-№ 4.-С. 154-158.

2. Вагин Ю. В. Дарвиновский отбор на пренатальной стадии онтогенеза у норок Mustela vison: генетико-физиологический механизм действия. // Доп. НАН України.- 2004.-№ 5.-С. 164-168.

3. Мазер К., Джинкс Дж. Биометрическая генетика.-М.: Мир, 1985.-463 с

4. Евсиков В. И. Генетические и феногенетические основы регулирования плодовитости млекопитающих: Автореф. дис. ... докт. биол. наук.-Новосибирск, 1974.-44 с.

5. Беляев Д. К., Железова А. И. Генетика плодовитости животных. Сообщ. 2. Некоторые физиологические особенности размножения мутантных норок // Генетика.- 1968.-4, № 1.-С. 45-57.

6. Гулевич Р. Г., Клочков Д. В. Гнетические особенности эндокринной функции половых желез у норок // Эндокринология размножения пушных зверей.-Новосибирск: Ин-т цитологии и генетики СО РАН, 1992.-C. 54-77.

7. Вагин Ю. В. Влияние гена aleutian на рост норок Mustela vison // Цитология и генетика.-2003.-37, № 4.-С. 16-19.

8. Fisher $R$. $A$. The genetical theory of natural selection.- Oxford: Clarendon Press, 1930.-435 p.

9. Тимофеев-Ресовский Н. В., Яблоков А. В., Глотов Н. В. Очерк учения о популяции.-М.: Наука, 1973.-277 с.

10. Dobzhansky Th. Genetics of the evolutionary process.-New York: Columbia Univ. Press, 1970.-505 p.

11. Шмальгаузен И. И. Факторы эволюции. Теория стабилизирующего отбора.-М.: Наука, 1968.-451 с.

12. Шмальгаузен И. И. Кибернетические вопросы биологии.-Новосибирск: Наука, 1968.-223 с.

13. Рэфф P., Кофмен T. Эмбрионы, гены и эволюция.-М.: Мир, 1986.-402 с

14. Гилберт С. Биология развития.-М.: Мир, 1995.-352 с.

15.Уоддингтон $K$. Морфогенез и генетика.-М.: Мир, 1964.-259 c. 
16. Гершензон C. М. «Мобилизационный резерв» внутривидовой изменчивости // Журн. общ. биологии.-1941.-2, № 1.- C. 85-107.

17. Lerner I. M. Genetic homeostasis.-Edinburgh: Oliver and Royd, 1954.-134 p.
18. Кимура М. Молекулярная эволюция: теория нейтральности.-М.: Мир, 1985.-394 с.

УДК $577.21+575.857$

Надійшла до редакції 15.05.07 